\section{Report of Candidatus Mycoplasma} haematoparvum and Mycoplasma haemocanis canine infections in Massambaba restinga, Brazil

Relato de infecções naturais caninas por Candidatus Mycoplasma haematoparvum e Mycoplasma haemocanis na Restinga de Massambaba, Brasil

\author{
Marcia Miranda', Bruno Alberigi* (D), Flavya Mendes-de-Almeida ${ }^{3}$ (D), Alexandre Bendas ${ }^{4}$ (D), Nadia Almosny ${ }^{3}$, \\ Jonimar Paiva ${ }^{4+} \&$ Norma Labarthe ${ }^{5}$ (D) \\ 'Veterinarian, Msc. Faculdade de Veterinária, Universidade Castelo Branco (UCB), Rio de Janeiro, RJ, Brasil \\ Veterinarian, DSc. Programa de Pós-graduação em Medicina Veterinária (PPGMV), Departamento de Medicina e Cirurgia \\ Veterinária (DMCV) Instituto de Veterinária (IV), Universidade Federal Rural do Rio de Janeiro (UFRRJ), Seropédica, RJ, Brasil \\ ${ }^{3}$ Veterinarian, DSc. Departamento de Patologia e Clínica Veterinária, Universidade Federal Fluminense (UFF), Niterói, RJ, Brasil \\ ${ }^{4}$ Veterinarian, DSc. DMCV, IV, UFRRJ, Seropédica, RJ, Brasil \\ 5Veterinarian, DSc. Programa de Pós-graduação em Bioética, Ética e Saúde Coletiva, Fundação Oswaldo Cruz - Fiocruz, Rio de \\ Janeiro, RJ, Brasil \\ ${ }^{\dagger}$ Deceased
}

\begin{abstract}
Tick-borne diseases are frequent in the southeastern section of Brazil. The most prevalent canine parasites diagnosed are Ehrlichia canis, Babesia gibsoni, Babesia canis, and Anaplasma platys, although Mycoplasma haemocanis and Candidatus Mycoplasma haematoparvum have also been detected in other regions of the country. Two clinically healthy dogs from a suburban area of the state of Rio de Janeiro had a history of being heavily infested with ticks and were examined at IDEXX Reference Laboratories, California for a tick panel check. One dog harbored DNA of Candidatus Mycoplasma haematoparvum and the other, the DNA of Mycoplasma haemocanis. These results reinforce the need for permanent monitoring for tick infestations and tick-borne parasites in southeastern Brazil, particularly considering the likely continuation of global climate changes that will contribute to the spread and increase of infections across the country.
\end{abstract}

Keywords: ticks, mycoplasmosis, canine parasites.

\section{Resumo}

Doenças transmitidas por carrapatos são frequentes na região sudeste do Brasil. Os parasitas caninos mais prevalentes diagnosticados são Ehrlichia canis, Babesia gibsoni, Babesia canis e Anaplasma platys, embora Mycoplasma haemocanis e Candidatus Mycoplasma haematoparvum tenham sido registrados no país. Dois cães clinicamente saudáveis de uma área suburbana do estado do Rio de Janeiro, Brasil, com histórico de forte infestação por carrapatos, foram examinados no Idexx Reference Laboratories, Califórnia, para verificação do painel de carrapatos. Um cão abrigava DNA de Candidatus Mycoplasma haematoparvume o outro DNA de Mycoplasma haemocanis. Esses resultados sugerem que o monitoramento de infestações e parasitas transmitidos por carrapatos deve ser permanente no sudeste do Brasil, principalmente devido às mudanças climáticas globais que podem contribuir para a disseminação e para o aumento do número de infecções no país.

Palavras-chave: carrapatos, micoplasmose, parasitas.

\section{Introduction}

Tick infestations and tick-borne diseases are commonly diagnosed in Brazilian dogs, especially in those allowed to roam free outside of their homes (Juan szabó et al., 2001; Labarthe et al., 2003). Therefore, routine examination of dogs should always include a determination of whether the animal is or has been infected with tick-transmitted parasites. In Brazil, Ehrlichia canis, Babesia gibsoni, Babesia canis, and Anaplasma platys circulate among dogs in regions of the country where ticks are frequently reported (Moreira et al., 2003). Molecularly confirmed Mycoplasma haemocanis was first reported in 2003 (De Morais, 2003) and Candidatus Mycoplasma haematoparvum, in 2008 (Santos et al., 2008). Mycoplasma spp. infections are seldom diagnosed in the country and

\section{BJ $\mathrm{M}$ \\ Brazilian Journal of Veterinary Medicine}

p-ISSN 0100-2430

How to cite: Miranda, M., Alberigi, B. Mendes-de-Almeida, F., Bendas, A., Almosny, N., Paiva, J., \& Labarthe, N. (2020). Report of Candidatus Mycoplasma haematoparvum and Mycoplasma haemocanis canine infections in Massambaba restinga, Brazil. Brazilian Journal of Veterinary Medicine, 42, e000420. https://doi. org/10.29374/2527-2179.bjvm000420

Financial support: MM, BA, FMA, JP-None. NL, NA-Scholarship provided by National Council for Scientific and Technological Development(CNPq) AB - The present work was carried out with the support of the Coordination of Improvement of Higher Education Personnel - Brazil (CAPES - Coordenação de Aperfeiçoamento de Pessoal de Nível Superior)

Conflict of interests: MM, BA, FMA, AB, NA, JP, - None. NL - Norma Labarthe is a consultant for Bayer animal health, Idexx Laboratories and Zoetis in Brazil.

Received: October 26, 2020.

Accepted: November 4, 2020.

The study was carried out at Universidade Federal Fluminense - UFF, Niterói, RJ, Brasil and Fundação Oswaldo Cruz - Fiocruz, Rio de Janeiro, RJ, Brasil.

\section{*Correspondence}

Bruno Alberigi

Departamento de Medicina e Cirurgia Veterinária, Instituto de Veterinária - IV, Universidade Federal Rural do Rio de Janeiro - UFRRJ

Rodovia BR 465, Km 7, Campus Universitário, Bairro Zona Rural

CEP 23897-000 - Seropédica (RJ), Brasil

E-mail: bruno.alberigi@gmail.com

Copyright Miranda et al. This is an Open Access article distributed under the terms of the Creative Commons Attribution Non-Commercial License which permits unrestricted non-commercial use, distribution, and reproduction in any medium provided the original work is properly cited. 
have never been reported from the Massambaba restinga region of the state of Rio de Janeiro. Mycoplasma haemocanis and Candidatus M. haematoparvum have been reported in metropolitan Rio de Janeiro. The aim of this study was to report the occurrence of Mycoplasma spp. infection in healthy dogs from a suburban area of the eastern section of the state of Riode Janeiro, Brazil, where these pathogens have been poorly studied.

\section{Materials and methods}

The present study was approved by the Comissão de Ética em Pesquisa Animal of the Universidade Federal Fluminense, Niterói, RJ, Brazil (protocol number 00128/09). Two free-roaming, clinically healthy dogs from a suburban area of the state of Rio de Janeiro (22.924170S; 42.224310W) were found seropositive for Anaplasma phagocytophilum by an ELISA test (SNAP TEST 4Dx ${ }^{\circledR}$, IDEXX Laboratories, Westbrook, Maine, USA). In the absence of clinical or hematological signs, DNA samples were sent for examination by a qPCR tick panel at the IDEXX Reference Laboratories in West Sacramento, California, USA.

\section{Results}

The dogs were found to harbor the DNA of two rare Mycoplasma species-Candidatus $M$. haematoparvum and M. haemocanis. The infection with A. phagocytophilum was not confirmed.

\section{Discussion}

The vast majority of canine infections with Candidatus M. haematoparvum and M. haemocanis are asymptomatic, even though the pathogens present a strong tropism for red blood cells and may cause hemolysis. Clinical signs are typically presented only if the dogs are immunocompromised or splenectomized, and include weight loss, anemia, and lethargy (Lester et al., 1995; Messick, 2003; Kemming et al., 2004). Therefore, because infected but immunocompetent dogs usually present no clinical signs, specific laboratory tests are not included in routine differentials.

In addition, most blood samples are sent to the laboratory as whole blood with an anticoagulant, usually edetic acid (EDTA). When whole blood is mixed with anticoagulants, the parasitic forms of hemotropic Mycoplasma are separated from the erythrocytes, impairing their visualization under light microscopy. These properties likely contribute to an underestimation of the prevalence of these canine infections. Further, since the pathogens are not included in differential diagnosis, missed cases contribute to keeping their true levels unknown and allowing them to remain in circulation. In Brazil, to date, few recent reports of these bacterial infections exist for the southeastern region, although they have been reported more commonly in the northeastern, mid-central, and southern regions (De Morais, 2003; Santos et al., 2008).

This report suggests that these asymptomatic, A. phagocytophilum antibody-positive dogs that did not harbor A. phagocytophilum DNA had been exposed to infected ticks but overcame the disease (Aguero-Rosenfeld et al., 2000). Canine tick-related infections may be subclinical (Messick, 2003; Kemming et al., 2004) and tick infestations are common around the country (Dantas-Torres et al., 2006), favoring an on-going parasite presence once an area has been colonized. Furthermore, global climate changes are spreading the geographical distribution of arthropods, which will affect their worldwide distribution.

\section{Conclusions}

These results highlight the need for monitoring tick infestations and tick-borne parasites as a permanent practice in southeastern Brazil. This is especially important considering that global climate changes will likely contribute to their spread and to an increased number of infections in the country.

\section{References}

Aguero-Rosenfeld, M. E., Kalantarpour, F., Baluch, M., Horowitz, H. W., McKenna, D. F., Raffalli, J. T., Hsieh, T. C., Wu, J., Dumler, J. S., \& Wormser, G. P. (2000). Serology of culture-confirmed cases of human granulocytic ehrlichiosis. Journal of Clinical Microbiology, 38(2), 635-638. http://dx.doi.org/10.1128/JCM.38.2.635-638.2000. PMid:10655359. 
Dantas-Torres, F., Figueredo, L. A., \& Brandão-Filho, S. P. (2006). Rhipicephalussanguineus (Acari: Ixodidae), the brown dog tick, parasitizing humans in Brazil. Revista da Sociedade Brasileira de Medicina Tropical, 39(1), 64-67. http://dx.doi.org/10.1590/S0037-86822006000100012. PMid:16501769.

De Morais, H. S. A. (2003). Mycoplasma haemocanis (previously Haemobartonellacanis) in non-splenectomized dogs in Brazil: 4 cases (1999-2001). Journal of Veterinary Internal Medicine, 17(3), 421.

Juan szabó, M. P., Marquez Cunha, T., Pinter, A., \& Vicentini, F. (2001). Ticks (Acari: Ixodidae) associated with domestic dogs in Franca region, São Paulo, Brazil. Experimental \& Applied Acarology, 25(10-11), 909-916. http:// dx.doi.org/10.1023/A:1020433003028. PMid:12455880.

Kemming, G., Messick, J. B., Mueller, W., Enders, G., Meisner, F., Muenzing, S., Kisch-Wedel, H., Schropp, A., Wojtczyk, C., Packert, K., Messmer, K., \& Thein, E. (2004). Can we continue research in splenectomized dogs? Mycoplasma haemocanis: old problem--new insight. European Surgical Research, 36(4), 198-205. http://dx.doi. org/10.1159/000078853. PMid:15263824.

Labarthe, N., de Campos Pereira, M., Barbarini, O., Mckee, W., Coimbra, C. A., \& Hoskins, J. (2003). Serologic prevalence of Dirofilariaimmitis, Ehrlichiacanis, and Borreliaburgdorferi infections in Brazil. Veterinary Therapeutics: Research in Applied Veterinary Medicine, 4(1), 67-75. PMid:12756637.

Lester, S. J., Hume, J. B., \& Phipps, B. (1995). Haemobartonellacanis infection following splenectomy and transfusion. The Canadian Veterinary Journal. La Revue Veterinaire Canadienne, 36(7), 444-445. PMid:7585424.

Messick, J. B. (2003). New perspectives about Hemotrophic mycoplasma (formerly, Haemobartonella and Eperythrozoon species) infections in dogs and cats. The Veterinary Clinics of North America. Small Animal Practice, 33(6), 1453-1465. http://dx.doi.org/10.1016/j.cvsm.2003.08.002. PMid:14664208.

Moreira, S. M., Bastos, C. V., Araújo, R. B., Santos, M., \& Passos, L. M. F. (2003). Retrospective study (1998-2001) on canine ehrlichiosis in Belo Horizonte, MG, Brazil. Arquivo Brasileiro de Medicina Veterinária e Zootecnia, 55(2), 141-147. http://dx.doi.org/10.1590/S0102-09352003000200003.

Santos, A., Stedile, R., Oliveira, S., Halik, L., Gonzalez, F., \& Messick, J. (2008). Detection of 'candidatus Mycoplasma turicensis'-like organism in dogs from Brazil.: 26. Veterinary Clinical Pathology, 37. 